Carina Rossa*

ORCID: 0000-0001-7290-0217

Watykan

\title{
Uniwersytet i szkoła. Promocja uniwersytetu otwartego. IV Międzynarodowy Kongres Cattedre Scholas, Castelgandolfo, 27-29 czerwca 2018 r.
}

Myśl papieża Franciszka prezentowana podczas różnych spotkań, w przemówieniach, dokumentach i publikacjach jest na tyle bogata, także pod względem treści dotyczących pedagogiki i formacji społecznej, że jest on uznawany za mistrza naszych czasów. Papież jest ceniony także poza kręgiem Kościoła katolickiego i chrześcijaństwa. Warto zatem nie tylko propagować jego myśl, lecz także uważnie i skrupulatnie ją przestudiować. Przesłanie papieża skierowane do kobiet i mężczyzn w czasach naznaczonych wojnami, niesprawiedliwością, niezrozumieniem i brakiem tolerancji ukazuje perspektywę nowego humanizmu, którego wszyscy potrzebujemy.

Dla pogłębienia myśli papieża Franciszka na temat wychowania oraz wydobycia z niej kierunków do działania pedagogicznego w różnych kontekstach, w których wychowuje się ludzi młodych, powstała idea Cattedre Scholas (Katedr Szkolnych). Jest to forum na poziomie akademickim, któ-

* Dr Carina Rosa, argentyńska psychopedagog, doktor pedagogiki na Uniwersytecie LUMSA w Rzymie, członek Rady Zarządu i koordynator Papieskiej Fundacji Scholas Occurrentes przy Stolicy Apostolskiej. Adres: Piazza San Calisto 16, 00120, Città del Vaticano; e-mail: carina.rossa@scholasoccurrentes.org. 
rego celem jest zgłębienie, realizowanie i promocja pedagogii papieża Franciszka. Katedry działają na całym świecie, a ich członkowie spotykają się corocznie na kongresach naukowych, aby podzielić się wynikami poczynionych badań i refleksji. Pierwszy taki kongres odbył się w Papieskiej Akademii Nauk w Watykanie (2015), drugi w Walencji w Hiszpanii (2016), trzeci na Uniwersytecie Hebrajskim w Jerozolimie (2017).

IV Międzynarodowy Kongres Katedr Scholas odbył się w Pałacu Papieskim w Castel Gandolfo w dniach 27-29 czerwca 2018 r. i był poświęcony refleksji nad rolą instytucji kształcenia na poziomie uniwersyteckim w zmaganiu się z wielkimi problemami ludzkości. W kongresie wzięło udział 245 naukowców pochodzących z 30 krajów na pięciu kontynentach i reprezentujących 75 uniwersytetów. Wśród nich: najstarsza Alma Mater - Uniwersytet Boloński (Włochy), Fordham University (USA), muzułmański l'Ishik University (Irak), L'Université Catholique Du Congo (Kongo) i Unilasalle Canoas (Brazylia).

Trzy główne bloki tematyczne dotyczyły następujących zagadnień: „Wychowanie do solidarnego humanizmu”; „Wyzwania wobec integralnego rozwoju w świetle encykliki Laudato Si "; „Dialog międzyreligijny i międzykulturowy na rzecz pokoju". Na temat wychowania do solidarnego humanizmu głos zabrali liczni i wybitni mówcy, m.in.: bp Vincenzo Zani, sekretarz Kongregacji ds. Edukacji Katolickiej przy Stolicy Apostolskiej (Watykan), prof. Andrew Furco z Minnesota University (USA) - znany w świecie ekspert w zakresie Service Learning, oraz o. Michael Smith SJ z International Education Officer for Jesuit Refugee Service (Nowa Zelandia). W sesji poświęconej zagadnieniom dotyczącym wyzwań wobec integralnego rozwoju w świetle encykliki Laudato Si 'mówili m.in.: prof. Francisco Carballo z Wydziału Polityki i Stosunków Międzynarodowych - Goldsmiths na University of London (UK) oraz argentyński teolog Augusto Zampini z Dykasterii ds. Integralnego Rozwoju Człowieka przy Stolicy Świętej. Na temat znaczenia dialogu międzyreligijnego i międzykulturowego w budowaniu pokoju dyskutowali: prof. Alfonso de Toro, dyrektor Południowoamerykańskiego Seminarium Badawczego i Centrum Badań Francuskojęzycznych na Universität Leipzig (Niemcy), rabin Daniel Goldman z Instytutu ds. Dialogu Międzyreligijnego (Instituto para el Diálogo Interreligioso, Argentyna) oraz dr Flavio Lotti z Państwowego Centrum Koordynowania Regionalnych Instytucji na rzecz Pokoju i Praw Człowieka (Coordinamento Nazionale enti locali per la Pace e diritti umani - Włochy). 


\section{Katedry Scholas}

Katedry Scholas są to miejsca zarówno refleksji naukowej, jak i konkretnego działania, połączone siecią, w której każdy podmiot (nauczyciele, naukowcy, studenci) ubogaca się poprzez spotkanie z drugim, poprzez współpracę między uniwersytetami, szkołami oraz projektami zarządzanymi na platformie Scholas Social. W tym kontekście szczególne miejsce zajmuje dialog pomiędzy różnymi religiami. Międzykulturowy i międzyreligijny charakter uniwersytetów uczestniczących w projekcie Scholas stanowi ogromne zaplecze bogactwa i aktywizacji w tworzeniu świata bardziej solidarnego i pokojowego. Dialog jest niezbędny w procesie osobistego dojrzewania, ponieważ wzrasta się i dojrzewa w konfrontacji z drugą osobą, z innymi kulturami, a także we właściwe pojętej konfrontacji z innymi religiami. Taki dialog przyczynia się do pokoju - stwierdza papież Franciszek ${ }^{1}$.

Wierne metodzie spotkania oraz czujne wobec otaczającej rzeczywistości, Katedry Scholas wychodzą od aktualnych problemów i kwestii, ku którym papież Franciszek na bieżąco kieruje naszą uwagę. Dla przemieniania owej rzeczywistości niezbędna jest refleksja nie tylko na płaszczyźnie akademickiej, lecz także gruntowne spojrzenie na aktywizujące metody wychowania, aby móc łączyć wiedzę z działaniem, a dyskusję i analizy - z konkretną interwencją.

\section{Uniwersytety „wychodzące”}

Papież Franciszek wydał w roku 2017 nową konstytucję apostolską na temat uniwersytetów i wydziałów papieskich Veritatis Gaudium ${ }^{2}$. Jest ona częścią jego programu odnowy. Czytamy tam m.in.:

Nadeszła teraz pora, aby to bogate dziedzictwo spostrzeżeń i wystąpień, zweryfikowanych i ubogaconych, że tak powiem, ,na polu” przez wytrwały trud mediacji kulturowej i społecznej Ewangelii realizowanej przez Lud Boży w róż-

${ }^{1}$ Francesco, „Discorso agli studenti e ai professori del Collegio Seibu Gakuen Bunry Junior High School di Saitama, Tokyo. 21 agosto 2013" (Vatican: Libreria Editrice Vaticana), http:/w2.vatican.va/content/francesco/it/speeches/2013/august/documents/papafrancesco_20130821_collegio-saitama-giappone.html [9.10.2018].

${ }^{2}$ Francesco, Veritatis gaudium (Vatican: Libreria Editrice Vaticana, 2017). 
nych środowiskach kontynentalnych i w dialogu z różnymi kulturami, stało się widoczne w nadaniu studiom kościelnym cech tej mądrej i odważnej odnowy, jakiej wymaga przemiana misyjna Kościoła „wychodzącego”3.

Odnowa uniwersytetów wyznaczona została przez cztery główne kryteria:

1. Mistykę życia razem, która staje się zaczynem powszechnego braterstwa, aby ukonkretnić społeczny wymiar ewangelizacji, dając pierwszeństwo ostatnim, odrzucanym przez społeczeństwo. Ta mistyka ,umie spoglądać na świętą wielkość bliźniego, odkrywać Boga w każdym człowieku, znosić uciążliwości życia razem, trzymając się miłości Bożej, otwierać serce na miłość Bożą, by szukać szczęścia innych tak, jak szuka go ich dobry Ojciec"4.

2. Dialog w jego pelni jako nieodłączny wymóg, by zyskać wspólnotowe doświadczenie oraz jako praktyka autentycznej kultury spotkania. Dlatego ,zachęca do wspierania dialogu z chrześcijanami należącymi do innych Kościołów i wspólnot kościelnych oraz z osobami należącymi do innych przekonań religijnych lub humanistycznych” oraz do tego, by ,współpracować również ze specjalistami innych dyscyplin naukowych, zarówno z wierzącymi, jak i niewierzącymi”, starając się ,,analizować i interpretować ich stwierdzenia, a także oceniać je w świetle prawdy objawionej"s. Wypływa stąd sposobność do rewizji programów studiów na różnych poziomach artykulacji dyscyplinarnej, pedagogicznej i dydaktycznej.

3. Inter i trans-dyscyplinarność realizowane $z$ mądrością i kreatywnością: chodzi o umożliwienie osiągnięcia, za pośrednictwem różnych programów proponowanych przez studia kościelne, wielu sukcesów naukowych odpowiadających wielopostaciowemu bogactwu rzeczywistości odkrytym przez wydarzenie Objawienia, będących jednocześnie harmonijnie i dynamicznie zebrane w jedności jego transcendentnego źródła oraz jego historycznej i metahistorycznej intencjonalności, jak to jest eschatologicznie dane w Jezusie Chrystusie 6 .

3 Ibidem, nr 3.

${ }^{4}$ Ibidem, nr 92.

5 Tamże, nr 4b; por. Sobór Watykański II, Gaudium et spes, w: Sobór Watykański II, Kostytucje, dekrety, deklaracje (Poznań: Pallottinum, 1967), nr 62.

${ }^{6}$ Francesco, Veritatis, nr 4c. 
4. Tworzenie sieci pomiędzy różnymi instytucjami, które w każdej części świata uprawiają i krzewią studia kościelne, zdecydowanie realizując niezbędne współdziałanie $\mathrm{z}$ instytucjami naukowymi w różnych krajach i z tymi, które są inspirowane innymi tradycjami kulturowymi i religijnymi. Trzeba też jednocześnie tworzyć wyspecjalizowane ośrodki badawcze mające na celu zbadanie problemów o znaczeniu epokowym, dotykających dziś ludzkość, i zaproponowanie odpowiednich i realistycznych dróg ich rozwiązania ${ }^{7}$.

Zaleca się zatem prowadzenie badań z uwzględnieniem rzeczywistości, ukierunkowanych na troskę o Wspólny Dom, w obronie ubogich, poprzez tworzenie sieci szacunku i braterstwa.

\section{Jakie wyzwania przed ,wychodzącymi” Katedrami Scholas?}

Na zakończenie Kongresu zostały sformułowane nowe wyzwania w świetle konstytucji apostolskiej Veritatis Gaudium, które określono następująco:

1. Wyzwania akademickie: zauważa się potrzebę promowania metod nauczania „poza aulą" po to, aby studenci mogli wejść w kontakt z lokalną wspólnotą, a jej obszar stał się źródłem specyficznego nauczania i praktyki stosowanej na rzecz rozwiązywania realnych problemów. Trzeba wymyślić takie strategie, aby w ramach wiedzy społecznie pożytecznej student miał możliwość nauczenia się stosowania języka głowy, serca i rąk $^{8}$. Potrzebna jest zatem większa spójność pomiędzy dyscyplinami naukowymi oraz nauczaniem, badaniami i społeczną odpowiedzialnością uniwersytetu. W tym celu do metod najczęściej stosowanych przez Katedry Scholas należy pedagogiczna propozycja uczenia się przez służenie.

2. Badania i zarządzanie wiedzą: badania powinny być ukierunkowane na rozwój wiedzy społecznie pożytecznej, która będzie owocem współpracy wspólnoty nawiązywanej poprzez sieć z innymi uniwersytetami. Należy stwarzać przestrzenie do takich działań ba-

${ }^{7}$ Por. tamże, nr 4d.

${ }^{8}$ „Discorso del Santo Padre Francesco in occasione della Chiusura del IV Congresso Mondiale Educativo delle «Scholas Occurrentes». Aula del Sinodo, Giovedi, 5 febbraio 2015" (Vatican: Libreria Editrice Vaticana), https://w2.vatican.va/content/francesco/it/speeches/2015/ february/documents/papa-francesco_20150205_scholas-occurrentes.html [9.10.2018]. 
dawczych, które za sprawą edukacji i ekonomii ukierunkowanej na służenie ludziom będą konkretną i krytyczną odpowiedzią na problemy wynikające z narzucanego systemu ekonomicznego charakteryzującego się „kulturą odrzucenia" powinni pracować $\mathrm{w}$ danym miejscu nad tymi samymi problemami poprzez tworzenie interdyscyplinarnej synergii między różnymi obszarami wiedzy. W taki właśnie sposób w minionym roku Katedry Scholas utworzyły 12 grup badawczych współpracujących w sieci pięciu lub sześciu uniwersytetów, które obrały ten sam temat. Badaniami objęto następujące obszary: sport a wychowanie, sztuka a wychowanie, wychowanie a nowe technologie, wychowanie włączające (inkluzyjne), zwolennicy spotkania, mobilność międzynarodowa, ruchy społeczne, migracje i uchodźcy, edukacja a zrównoważony rozwój, zrównoważony pokój, dialog międzykulturowy i międzyreligijny, społeczna odpowiedzialność uniwersytetu, pakt wychowawczy.

3. Zaangażowanie społeczne lub Trzecia Misja: wdrażanie projektów rozwojowych (przedmiotów) połączonych z badaniami stosowanymi jako źródła potencjału dydaktycznego dla wspólnoty uniwersyteckiej. Przewiduje się ponadto znaczny wzrost wolontariatu studenckiego, dzięki czemu studenci będą mogli zdobyć rozległą wiedzę. Dla osiągnięcia tego celu Scholas proponuje dwa programy: Scholas.social - platformę cyfrową zwierającą projekty i dobre praktyki (online i offline) jako źródło do badań, oraz program Scholas.cittadinanza, dzięki któremu uczniowie szkół średnich z danego miasta mogą spotykać się i współpracować, by wspólnie rozwiązywać problemy lokalnej społeczności.

4. Wewnętrzne zarządzanie uniwersytetem: uniwersytet postrzegany jako wzorcowa wspólnota społeczna, która urzeczywistnia pięć kryteriów Veritatis Gaudium. Zmierza się do tego, aby uniwersytet mógł być także przykładem zrównoważonego rozwoju, to znaczy, aby jako instytucja promował politykę ochrony środowiska i społecznego rozwoju.

9 Francesco, Udienza Generale. Piazza San Pietro, 5 giugno 2013 (Vatican: Libreria Editrice Vaticana), http://w2.vatican.va/content/francesco/it/audiences/2013/documents/papafrancesco_20130605_udienza-generale.html [9.10.2018]. 
Jak co roku, kongres Katedr Scholas był okazją do przedstawienia sprawozdań, dopracowania kryteriów jakości i otwarcia się na nowe wyzwania, ale przede wszystkim do spotkania przyjaciół kierujących się „Mistyką życia razem" w świecie akademickim. W 2019 r. z nowymi wyzwaniami przyjmie nas Fordham University w Nowym Jorku.

Ttumaczenie: Stanistaw Grochmal, Mariola Teresa Kozubek 
